\title{
STUDY OF HEMATOLOGICAL AND SERUM BIOCHEMICAL PROFILE IN PRE-PARTURIENT MURRAH CROSS BUFFALOES IN CHITWAN DISTRICT
}

\author{
R. Acharya ${ }^{1 *}$ and P.B. Pal ${ }^{2}$ \\ ${ }^{1}$ Institute of Agriculture and Animal Science, Paklihawa Campus \\ ${ }^{2}$ Agriculture and Forestry University, Rampur, Chitwan \\ (*email: rabin@iaas.edu.np)
}

\begin{abstract}
The aim of this study was to establish the reference values for hematology and serum biochemistry of pre-parturient Murrah crossbred buffaloes of Western Chitwan (Bharatpur Metropolitancity). The study was cross-sectional in which31 apparantly healthy pregnant Murrah cross buffaloes ranging from 5-8 years were selected randomly after confirmation by rectal palpation. Blood samples collected from jugular vein were stored in EDTA tubes for hematological analysis and for biochemical analysis centrifuged at $1500 \mathrm{rpm}$ for 20 minutes to separate serum after 1 hour of collection. Hematological indices were determined manually using routine laboratory techniques and serum biochemicals were analysed using automated analyzer (Dimension RXL). Serum biochemicals like Glucose, BUN, Creatinine, Calcium, Phosphorous, Magnesium, AST, $A L T$, total serum Protein and albumin level were found within the normal range. Similarly, hematologic indices $\mathrm{Hb}, \mathrm{PCV}$, Platelet counts, RBC counts, WBC counts, and differential leukocyte counts were also in normal ranges. However, eosinophil (7.83 \pm 0.82$)$, and monocyte (4.4 \pm 0.53$)$ counts were higher at significant numbers which suggests gastrointestinal parasitic infestations and/or allergic diseases along with some chronic infectious diseases in the buffalo herd of Bharatpur Metropolitancity in western Chitwan.
\end{abstract}

Keywords: Hematology, Blood-biochemistry, Pre-parturient, Buffalo

\section{INTRODUCTION}

Throughout the known history, buffaloes have been raised in Nepal and are the main source of meat and milk in the country. Buffaloes are also an important source of manure and draft power. Because of their multi uses, buffalo are more valuable than cattle in Nepal, atleast from an economic point of view. According to Rasali (2000), buffaloes are the key livestock species in Nepal contributing about $53 \%$ of the total livestock GDP, mainly through the production of milk and meat. Food and Agriculture Organization of the United Nations (2014), ranks Nepal on sixth in total buffalo milk production with the estimate of 1167773 MT annually and simillar on animal population. The figures of buffalo products amounted to $71 \%$ of the total milk production and $60 \%$ of the total meat production in the country (DLS, 2014).

Chitwan district in the central Terai is a major dairy pocket of the country contributing $2.5 \%$ of total milk production of which $70 \%$ (29866 MT) is from buffalo. The similar is 
with the total meat production in which the district alone produces 3.3\% in which buffalo shares 57\% (DLS, 2014). As per the government policy for buffalo improvement the activity of maintaining $62.5 \%$ of the Murrah breed blood level in Terai districts, through unrestricted artificial insemination (AI) with Indian Murrah semen has been running in the district since few decades (ABAIS,1997). Still intensive AI with frozen Murrah semen is being carried out since fiscal year 2068/069 via. AI Mission of Department of Livestock services (NLBC, 2016) the district at present has large number of Murrah cross buffaloes.

It has recently been proved that the metabolic profile (Complete hematological and biochemical) testing as a best tool for the assessment of dairy herd's nutritional status and is a pre-symptomatic diagnostic aid capable of giving early warning of certain types of metabolic derangement in dairy animals with simple blood test (Herdt et al., 2001). But these indices may vary depending on factors such origin, climate, management practice geographical distribution and in stages of animals. Cattle and buffaloes are more susceptible to metabolic derangements during peri-partum stage and prepartum period is more critical during which the cattle is most likely to render many metabolic disorders and also has sequel in postpartum like milk fever, hypomagnesaemia, retained placentas etc. (Bell, 1995). Moreover, the present study was aimed at assessment of different hematological and biochemical parameters of pregnant (pre-parturient) Murrah crossbreed buffaloes reared in the subtropical agro-climatic conditions of western Chitwan and to set the standard reference value.

\section{MATERIALS AND METHODS}

\section{Site of study}

The study was conducted in dairy pocket areas predominantly populated with dairy buffaloes inside Bharatpur Metropolitan city (i.e. Mangalpur, Bijayanagar, Shardanagar, and Shivanagar) of western Chitwan district.

\section{Surveying and selection of Buffaloes}

Surveying was done in all the four sites for the selection of pre-parturient Murrah cross buffaloes. Rectal palpation was done, and positive animals were selected. A total of 31 apparently healthy buffaloes ranging from 5-8 years old were included in the study.

\section{Blood Collection, serum separation and transportation}

Blood samples of all selected animals were collected from the jugular vein using vacutainer tubes. Blood for hematological analysis was stored in EDTA tubes (BD Vacutainer ${ }^{\circledR}$ with K2 EDTA $5.4 \mathrm{mg}$ ) while blood for biochemical analysis was allowed to stand $1 \mathrm{~h}$ at room temperature and transported in an ice pack thermocol to laboratory and centrifuged at $1500 \mathrm{rpm}$ for 20 minutes to separate serum. The blood samples were examined for hematological indices within 48 hours of blood collection and serum sample was stored at -20 degree centigrade until analysis.

\section{Analysis of blood and serum biochemicals}

i) Hematology: It was including total $\mathrm{RBC}$ counts, total WBC counts, differential leucocytes count, hemoglobin percentage ( $\mathrm{Hb} \%$ ), packed cell volume (PCV), Macro 
corpuscular volume (MCV), Microhematocrit hemoconcentration (MCHC) and platelet counts. These all indices were determined using routine laboratory techniques at Kohinoor Patho-lab, Bharatpur.

ii) Serum biochemicals: Serum biochemical estimation will include liver function assay (ALT, AST), glucose, protein (albumin and total protein), kidney function assay (Blood urea nitrogen and creatinine), and macro minerals ( $\mathrm{Ca}, \mathrm{P}$, and $\mathrm{Mg}$ ). These were analyzed by using automated analyzer (Dimension RXL) in B.P.K. Memorial Cancer Hospital, Chitwan.

\section{Bio-statistics and data analysis}

Descriptive statistical analysis was done by using computer software Microsoft Excel 2010 and results are expressed as Mean, Standard Deviation and Standard Error.

\section{RESULTS AND DISCUSSION}

The haematological results reveals $\mathrm{Hb}(\mathrm{gm} / \mathrm{dl}) 11.03 \pm 0.21, \mathrm{PCV}(\%) 33.83 \pm 0.51$, Platelet ( $\times 1000 / \mathrm{mm} 3) 566.33 \pm 20.24, \mathrm{MCV}$ (fl) $53.37 \pm 0.29, \mathrm{MCH}(\mathrm{pg}) 15.33 \pm 0.15, \mathrm{MCHC}(\%)$ $30.90 \pm 0.22, \mathrm{RBC}\left(\times 10^{6} / \mathrm{mm} 3\right) 6.33 \pm 0.10, \mathrm{WBC}(/ \mathrm{mm} 3) 8743.33 \pm 209.36$, Neutrophils $(\%)$

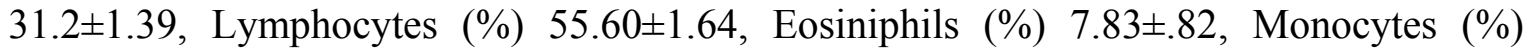
$4.4 \pm 0.53$ and Basophils (\%) 0.47 \pm 0.13 . Simillarly, results for biochemical values showed Glucose (gm/dl) 36.35 \pm 1.52 , BUN (mg/dl) 10.97 \pm 0.49 , Creatinine (mg/dl) $0.79 \pm 0.05$, Calcium (mg/dl) 6.76 \pm 0.20 , Phosphorous (mg/dl) 4.03 \pm 0.18 , Magnesium (mg/dl) $2.65 \pm 0.10$, AST (U/L) 138.13 \pm 6.47 , ALT (U/L) 70.68 \pm 2.90 , Total serum Protein (gm/dl) $6.03 \pm 0.22$ and Albumin $(\mathrm{gm} / \mathrm{dl}) 0.63 \pm 0.03$.

Table 1: Hematological values for pre-parturentMurrah crossbred Buffaloes in western Chitwan of Nepal*

\begin{tabular}{llll}
\hline Parameters & Unit & Mean \pm SE & Standard Deviation \\
\hline $\mathrm{Hb}$ & $\mathrm{gm} / \mathrm{dl}$ & $11.03 \pm 0.21$ & 1.15 \\
$\mathrm{PCV}$ & $\%$ & $33.83 \pm 0.51$ & 2.81 \\
Platelets & $\times 1000 / \mathrm{m}$ & $566.33 \pm 20.24$ & 110.85 \\
$\mathrm{MCV}$ & $\mathrm{fl}$ & $53.37 \pm 0.29$ & 1.61 \\
$\mathrm{MCH}$ & $\mathrm{pg}$ & $15.33 \pm 0.15$ & 0.84 \\
$\mathrm{MCHC}$ & $\%$ & $30.90 \pm 0.22$ & 1.18 \\
$\mathrm{RBC}$ & $\times 106 / \mathrm{mm}$ & $6.33 \pm 0.10^{* *}$ & 0.45 \\
$\mathrm{WBC}$ & $/ \mathrm{mm} 3$ & $8743.33 \pm 209.36$ & 1146.71 \\
$\mathrm{~N}$ & $\%$ & $31.2 \pm 1.3$ & 7.6 \\
$\mathrm{~L}$ & $\%$ & $55.60 \pm 1.64$ & 8.99 \\
$\mathrm{E}$ & $\%$ & $7.83 \pm 0.82$ & 4.48 \\
$\mathrm{M}$ & $\%$ & $4.4 \pm 0.53$ & 2.9 \\
$\mathrm{~B}$ & $\%$ & $0.47 \pm 0.13$ & 0.73 \\
\hline$* \mathrm{n}=30$ at $95 \%$ level ofsignificance; $* \mathrm{n}=20$ &
\end{tabular}


The result so obtained suggest for normal hematological and blood biochemical values within the range, but eosinophil and monocyte count were higher in the herd. Monocyte count quite similar with Canfield et al., (1984), more than Patil et al., (1992), Akhtaret al.,(2007), Salong et al., (1980) and Ciaramella et al.,(2005) which suggest subclinical chronic infectious disease in buffalo herd in the district. Eosinophil count were higher than Sharma et al., (1985), Canfield et al., (1984), Patil et al.,(1992), Akhtar et al., (2007), Salong et al., (1980) and Ciaramella et al., (2005) and the higher value suggests gastrointestinal parasitic infestation and/or some allergic diseases. Variations in monocytes also may be due to difficulty in seperation between large lymphocytesandmonocytes. Selection of animals to be sampled was most daunting task because uniform age and physical condition of animals cannot be expected in different herds in field condition, so the sampling problem of animals did exist which may be responsible for minor variation.

Table 2: Serum biochemicals values for pre-parturentMurrah crossbred Buffaloes in western Chitwan of Nepal*

\begin{tabular}{lllc}
\hline Parameters & Unit & Mean \pm SE & Standard Deviation \\
\hline glucose & $\mathrm{gm} / \mathrm{dl}$ & $36.35 \pm 1.52$ & 8.44 \\
BUN & $\mathrm{mg} / \mathrm{dl}$ & $10.97 \pm 0.49$ & 2.7 \\
Creatinine & $\mathrm{mg} / \mathrm{dl}$ & $0.79 \pm 0.05$ & 0.29 \\
$\mathrm{Ca}$ & $\mathrm{mg} / \mathrm{dl}$ & $6.76 \pm 0.20$ & 1.12 \\
$\mathrm{P}$ & $\mathrm{mg} / \mathrm{dl}$ & $4.03 \pm 0.18$ & 0.99 \\
$\mathrm{Mg}$ & $\mathrm{mg} / \mathrm{dl}$ & $2.65 \pm 0.10$ & 0.53 \\
$\mathrm{GOT} / \mathrm{AST}$ & $\mathrm{U} / \mathrm{L}$ & $138.13 \pm 6.47$ & 36.03 \\
$\mathrm{GPT} / \mathrm{ALT}$ & $\mathrm{U} / \mathrm{L}$ & $70.68 \pm 2.90$ & 16.13 \\
TP & $\mathrm{gm} / \mathrm{dl}$ & $6.03 \pm 0.22$ & 1.24 \\
Albumin & $\mathrm{gm} / \mathrm{dl}$ & $0.63 \pm 0.03$ & 0.18 \\
\hline
\end{tabular}

$* n=31$ at $95 \%$ level of significance

\section{CONCLUSION}

A reference for hematology and blood biochemical values for pre-parturient (last trimester) Murrah crossbred buffaloes for Bharatpur Metropolitan city (western Chitwan) established. High eosinophil and monocyte count so obtained suggests parasitic infestations and/or allergic diseases along with some chronic infectious disease in the buffalo herd of Bharatpur Metropolitan city.

\section{ACKNOWLEDGEMENT}

We are grateful to the staff of IAAS Livestock Farm, Rampur for the help during survey and blood collection. We would like to thank Professor Dr. M. C. Lee, Department of Pathology, B. P. Koirala Memorial Cancer Hospital, Bharatpur for his labrotary support in 
biochemical analysis. We are grateful to Mr. Madan Pandey, Director, Kohinoor Pathology Lab, Bharatpur, for his help in hematological works.

\section{REFERENCES}

ABAIS (1997).Annual Report-1996-97. Animal Breeding and Artificial Insemination Section, Department of Livestock Services, Kathmandu, Nepal.

Akhtar, M.Z., Khan, A., Khan, M.Z. and Muhammad, G. (2007). Haemato-biochemical aspects of parturient haemoglobinuria in buffalo. Turkish Journal of Veterinary and Animal Sciences, 31(2):119-123.

Bell, A.W. (1995). Regulation of organic nutrient metabolism during transition from late pregnancy to Regulation of Organic Nutrient Late Pregnancy Metabolism During Transition from to Early. Journal of Animal Science, 73(9):2804-2819. https://doi.org//1995.7392804x.

Canfield, P.J., Best, F.G., Fairburn, A.J., Purdie, J. and Gilham, M. (1984). Normal haematological and biochemical values for the swamp buffalo (Bubalus bubalis) in Australia. Australian veterinary journal, 61(3): 89-93.

Ciaramella, P., Corona, M., Ambrosio, R., Consalvo, F. and Persechino, A. (2005). Haematological profile on non-lactating Mediterranean buffaloes (Bubalus bubalis) ranging in age from 24 months to 14 years. Research in veterinary science, 79(1): 77-80.

DLS. (2014). Livestock statistics of Nepal -2012/13. Department of Livestock Services, Statistics Section, Lalitpur, Nepal.

Food and Agriculture Organization of the United Nations. (2014). FAOSTAT. Retrieved May 19, 2017, from http://www.fao.org/faostat/en/\#data/QL.

Herdt, T.H., Dart, B. and Neuder, L. (2001). Will large dairy herds lead to the revival of metabolic profile testing. In Proc Am AssocBovPract (34, pp. 27-34).

NLBC (2016). Annual Report - 2072/073. National Livestock Breeding Centre, Pokhara

Patil, M.D., Talvelkar, B.A., Joshi, V.G. and Deshmukh, B.T. (1992). Hematological Studies in Murrah Buffalos. Indian Veterinary Journal, 69(7): 661-663.

Rasali, D.P. (2000). Recent trends in buffalo production in Nepal- a review. Buffalo Newsletter 14: 6-10

Sharma, M.C., Pathak, M.N., Verma, R.P., Hung, N.N., Cu, N.V., Lien, N.H. and Vuc, N.V. (1985). Normal haematology of Murrah buffaloes of various ages in the agroclimatic conditions in Viet Nam. Indian Veterinary Journal (India).

Sulong, A., Jainudeen, M.R., \& Mohamad, H. (1980). Haematology of the Malaysian swamp buffalo (Bubalus bubalis). Pertanika, 3(2): 66-70. 